\title{
Planning of Integrated Land Use and Social Infrastructure of SAS Nagar, Mohali, Punjab
}

\author{
Harcharan Singh \\ Department of GRD School of Planning, GNDU, Amritsar, Punjab, India \\ E-Mail: harcharanriar1987@gmail.com
}

\begin{abstract}
The social infrastructure and needs of the various communities coexisting in a city are associated in considerably substantial and strong relationship with its surrounding environment. There are numerous parameters which influence the social infrastructure and community needs with respect to its integration with the land use of that city. Accessibility of proper terminals for public transportation, institutes, and hospitals parks etc. These parameters are studied along with parallel analysis of the total area covered and existing population of the city. Social infrastructures in a city have a large impact on the quality of life of the people in the urban centers. SAS Nagar (Mohali) is a counter magnet city of Chandigarh and one of the the most well-known planned city in Punjab, India. Mohali started developing as a counter magnet in the early 1990's. It was initially known as Mohali village, a part of the Union Territory of Chandigarh. Mohali inhere with phases/ sectors including the new industrial areas, commercial centers and the educational institutions like as $\mathrm{C}$ DAC Mohali in the vicinity of the residential areas. Mohali is spread over a total area of $167.67 \mathrm{sq}$. $\mathrm{km}$ out of which 32.58 sq. $\mathbf{k m}$ is under the MC area with is characterized by very well planned areas. Despite of being a well-planned city of Punjab, India; Mohali still have a shortage of appropriate opportunity of services with low openness to the needs of the people. This study focuses on the relationship between land use and the social infrastructure with emphasis on the relationship analysis with geospatial planning techniques. The quality of life of people depends on the accessibility to quality of social and community infrastructure; it also impacts the migration pattern and the movement of daily commuters for their various reasons in the city. The advancement of the city is being anticipated as per the increase of the urbanization along with accessibility to proper social infrastructure, which satisfies the essential \& functioning demand of the city. The development of the city is of two types' i.e. compact development and sprawl development (depends on the density of population per sq.km). The assessment study of community infrastructure and social needs of Mohali includes various types of operational functioning parameters for study like; directional analysis, population wise analysis and area wise analysis. These social and community infrastructural needs have their own norms and standards for the city level services and as well as neighbourhood level assistance, which categorize their accessibility for the integrated land use pattern and population for services. By using open source GIS, the served areas and un-served areas along with their names are bring classified properly as per the given parameters.

Keywords: Social Infrastructure Planning, Geospatial
\end{abstract} Technology (QGIS), Google Earth

\section{INTRODUCTION}

In the mechanism of Geospatial planning of land use integrated with the social infrastructure of a city, the quality of life in any urban area depends upon the accessibility and convenience to quality of social and community infrastructure. Social infrastructure can be consider in terms of efficiency of Community social needs, which are describe in the form of availability of Parks, hospitals, public transport terminals and police station and police peats in the city. There is a rapid increase in the population and urbanization in the cities because people are migrating from the rural areas to urban areas for better opportunities in jobs and quality of life. Reason of migration of people in Mohali is majorly because Mohali is the counter magnet city of the Chandigarh. It is a well-planned city with good surrounding environment and a lot opportunity of employment and education facilities. Due to this rapid urbanisation; there is a growing need of social infrastructure to fulfil the need of the people of Mohali. To study the role of evolution of social infrastructure which is related to the development of the city we need to study the Direction wise, Area wise and Location wise analysis of the social infrastructure and frameworks, which is a major factor in development of a city. Analysis of Social infrastructure with respect to spatial variation in characteristics within the SAS Nagar (Mohali). The location of SAS Nagar (Mohali) is in the South-East side of the Punjab, which is shown as follow.

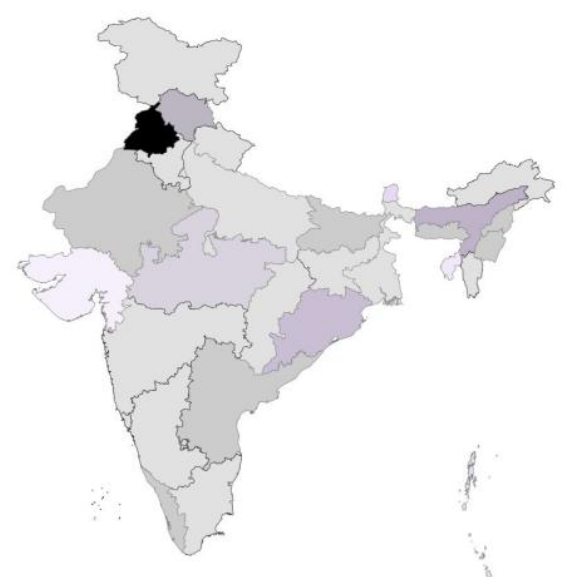

Fig.1 Location of Punjab (In Black) in India 


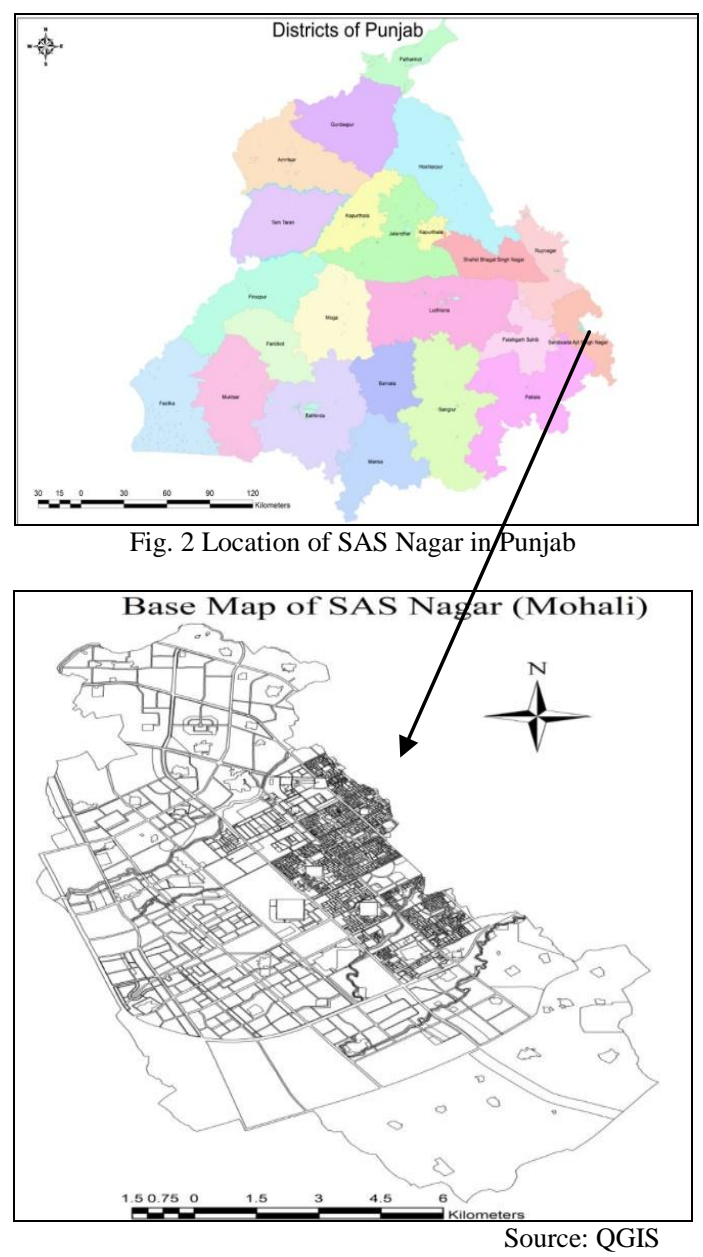

Fig. 3 Base Map of Mohali

\section{METHODOLOGY}

A. Selection of Topic: The topic is selected broadly depending upon what is the requirement of the research.

B. Introduction to the Site: first step of study includes study about the city \& the relevant Site (Mohali) including their important characteristics and detailed study of its existing features.

C. Formulation of the Objectives: The objective need to be prepared depending upon the topic and current scenario of the city. It mainly details of how the aim of the study is to be achieved.

D. Theoretical Framework: This includes the process of how the objectives are to be achieved in form of steps.

E. Preparation of Land use Map: The land use map is prepared, with reference to the existing land use map of SAS Nagar (Mohali), in QGIS. The map includes every information needed in the thesis.

F. Data Identification Kit: The data need to be identified that is to be collected. All the data that is required for the study needs to be included in the data kit. The data can be collected through primary survey (either from local peoples, visual survey, photographs, and general observations from visits) or secondary survey (from offices and authorities). The data can be in the form of table, literature and map.

G. Data Collection: Data is collected from various offices, departments and other secondary sources like Census etc. Some data might not be available and may require extensive primary survey.

H. Data Analysis: The data collected is updated in QGIS format or in excel for analysis and then present in various forms for analysis.

I. Research Paper Writing: A detailed study of the research work is the outline of the nature of the subject, its scope and a clear statement of objectives. It will show an analysis of the issues leading to the achievement of objectives, planning possibilities and phasing of development etc.

\section{NEED FOR SOCIAL INFRASTRUCTURE PLANNING}

Social infrastructure and framework plays a vital role in the formation of strong, healthy and sustainable communities. It basically includes good schools, health facilities, parks, transportation opportunities etc. Communities need to be actively incorporated in the planning of services. A strategic approach has to be taken in outlining, planning and arrangement of framework or infrastructure.

\section{ISSUES AND PROBLEMS RELATED TO SPATIAL DISTRIBUTION OF SOCIAL INFRASTRUCTURE}

Problems related to spatial distribution as following.

A. Location: It is a very important aspect that where the component of social framework or infrastructure is placed with respect to the existing land use.

B. Land Use Distribution: By the study of existing land use, it basically reflects the substantial expansion, advance pattern and functional formation of the area. The Geospatial formation of the city is a reflection of integration of different land uses in different parts of the city. Also, the substantial and physical advancement of the city reflects the nature and degree of improvement in various directions of a city.

C. Demographic Characteristics: Demographic characteristics have a strong impact on study of the urban formation of the city. Density of population has been the most tested component of the framework to illustrate the formation of city at its micro level. By the help of ward wise population of the city and sector wise population in SAS Nagar (Mohali) detailed density wise analysis of the ward is done to analyze the requirement of re densification. 


\section{DISTRIBUTION PATTERN OF LAND USE IN SAS NAGAR, MOHALI}

The assessment of land use pattern of the city has been done in QGIS It is clear from the fig no. 5. Area is calculated in km.sq. \& in hectares. SAS Nagar having a total area of $167.674 \mathrm{~km} . \mathrm{sq}$ (16767.4 hectares). The Land use distribution of SAS Nagar (Mohali) is calculated by the QGIS software by area calculation technique. It also calculates the total developed and undeveloped area of SAS Nagar (Mohali. A major part of land is under Transportation and then the open land use (14\%) and $16 \%$ is vacant land because of various new development proposals such as Aero city and Knowledge park (new industrial land use) and various type of mixed land use area along with the Aero city to the north-eastern side of the 80 sector in SAS Nagar (Mohali).

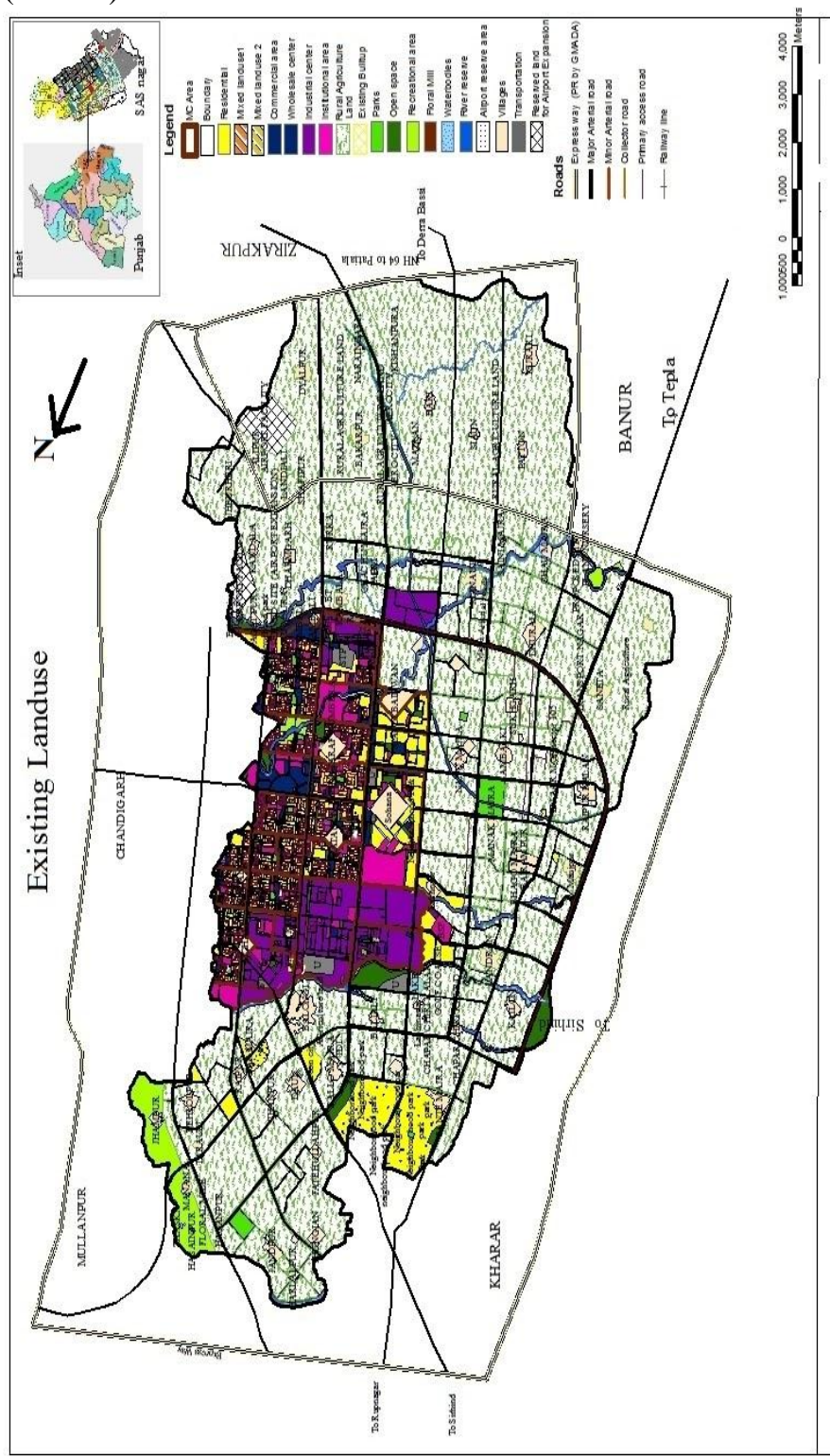

Source: Prepared by Author by using SAS Nagar Master Plan, Google Earth and QGIS

Fig. 4 Existing Land use of SAS Nagar (Mohali)
As per the Existing Land Use of SAS Nagar (Mohali) in comparison with URDPFI guidelines it shows that residential area, recreational area $\&$ institutional areas are inadequate with respect to the URDPFI guidelines and commercial land use, industrial land use and circulation land use are adequate as per the guidelines. The area like agriculture land, water bodies \& open spaces are calculated as undeveloped areas and the rest of land uses are calculated as developed land use areas. The $47 \%$ of total land use are calculated as developed areas and $53 \%$ of the total land use areas are calculated as undeveloped areas, because maximum area is covered by the agriculture land and open spaces. The distribution is shown in the fig. no. 5 as given below

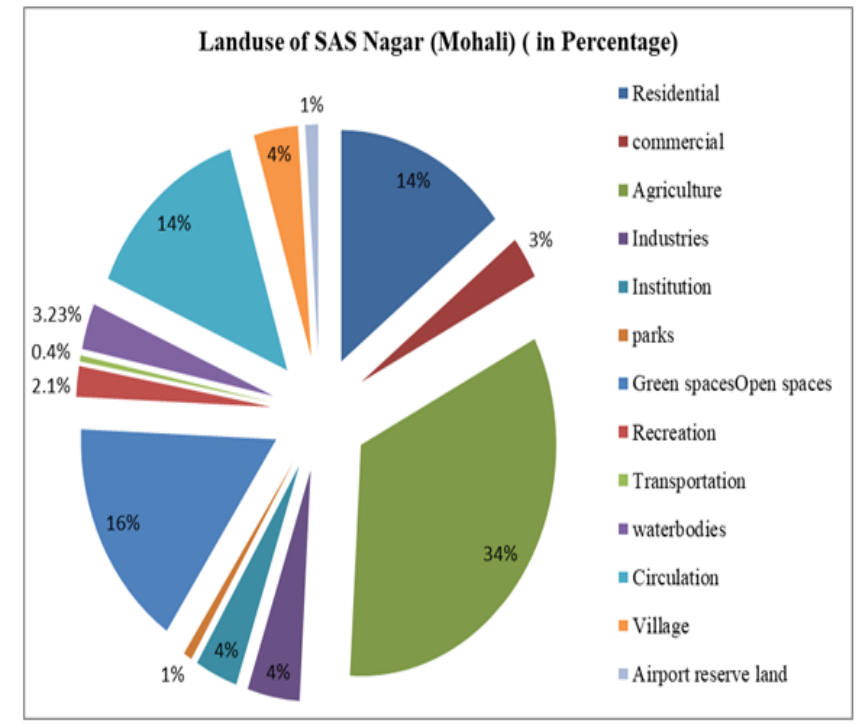

Source: Primary Calculated Vat
Fig. 5 Land Use of SAS Nagar (Mohali)

\section{A. Total Area of the Developed and Undeveloped Area}

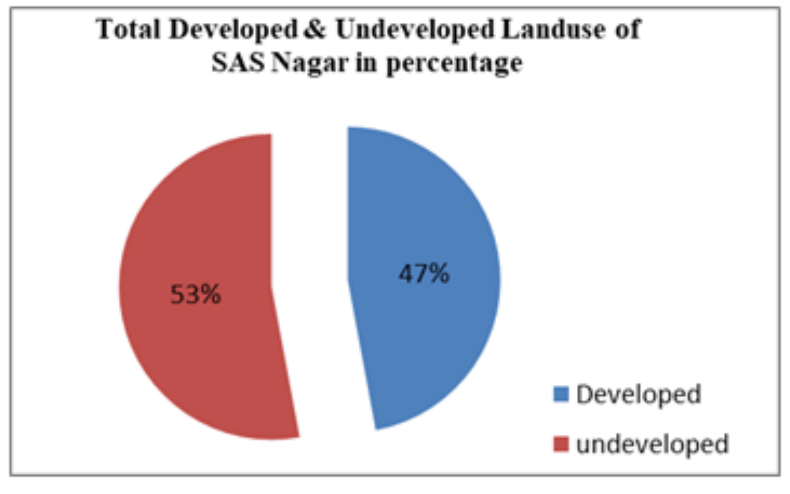

Source: Primary Calculated Value in QGIS

Fig. 6 Total Developed \& Undeveloped area of SAS Nagar (Mohali)

In the MC of SAS Nagar (Mohali), It is clear from the table that there have been variations in the total area of the MC. SAS Nagar (Mohali) MC area having a total area of 3258 hectares. The distribution is shown in the pie diagram as given below. 


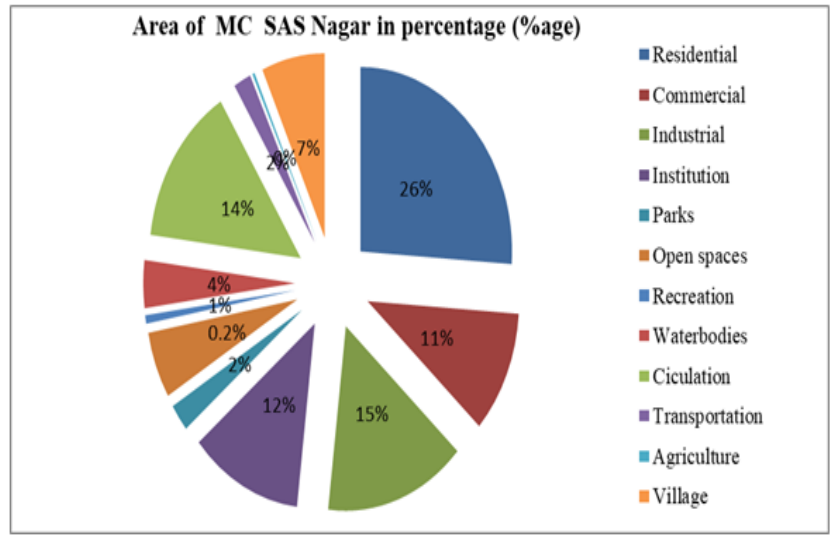

Fig. 7 Land Use of MC area of SAS Nagar (Mohali)

SAS Nagar (Mohali) MC covers total area of 32.58 sq.km area (3258 hectares). In SAS Nagar (Mohali) there are very little open spaces or reserved area for further development of categories of land use. Mainly these open spaces are used for parks, residential areas, institutional areas and industrial areas etc.

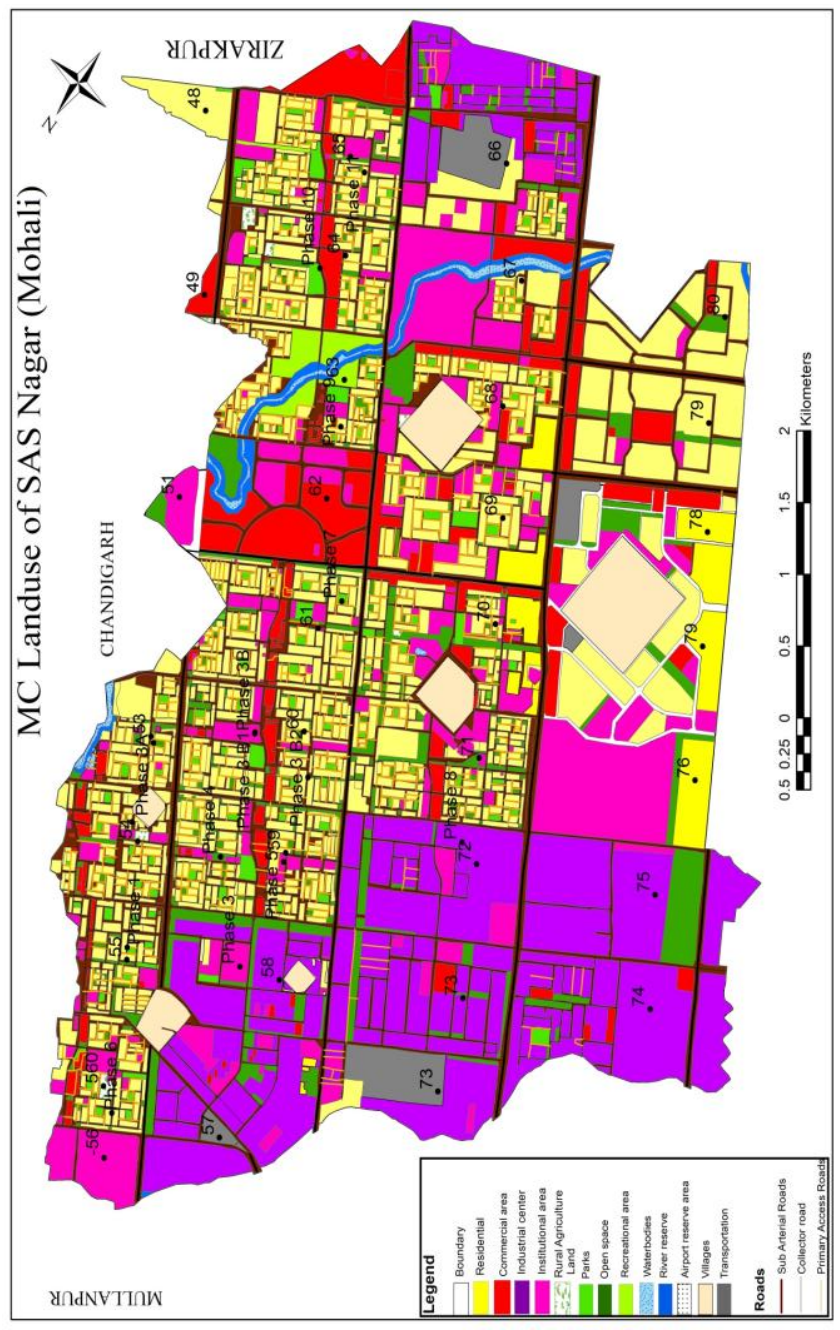

Source: Prepared by Author by using Google Earth \& QGIS and MC SAS Nagar (Mohali) (2016)

Fig. 9 MC Ward and Sector boundary of Mohali
Thus nearly, $90 \%$ of the area within the M.C limits has already been developed for various uses such as residential, commercial, industrial etc. and $10 \%$ remain undeveloped, the areas like as agriculture land, area under water bodies and open spaces are not included in developed area.

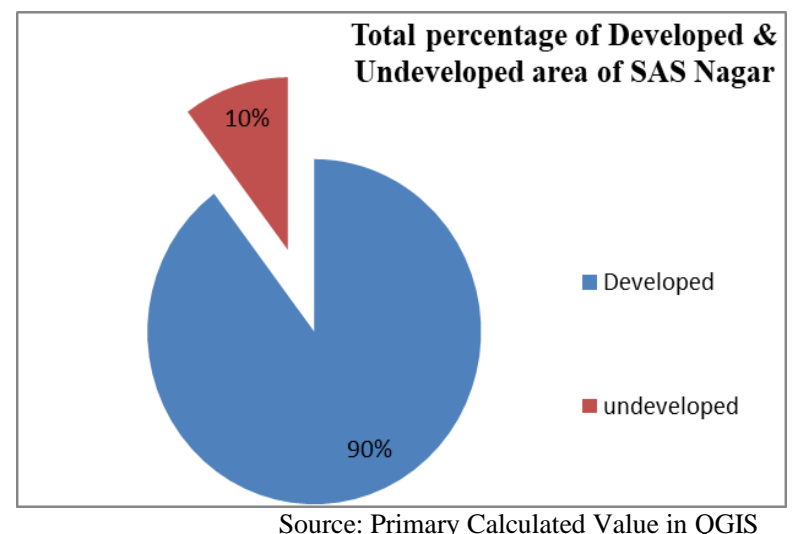

Fig. 8 Land Use of Developed area of MC area of SAS Nagar (Mohali)

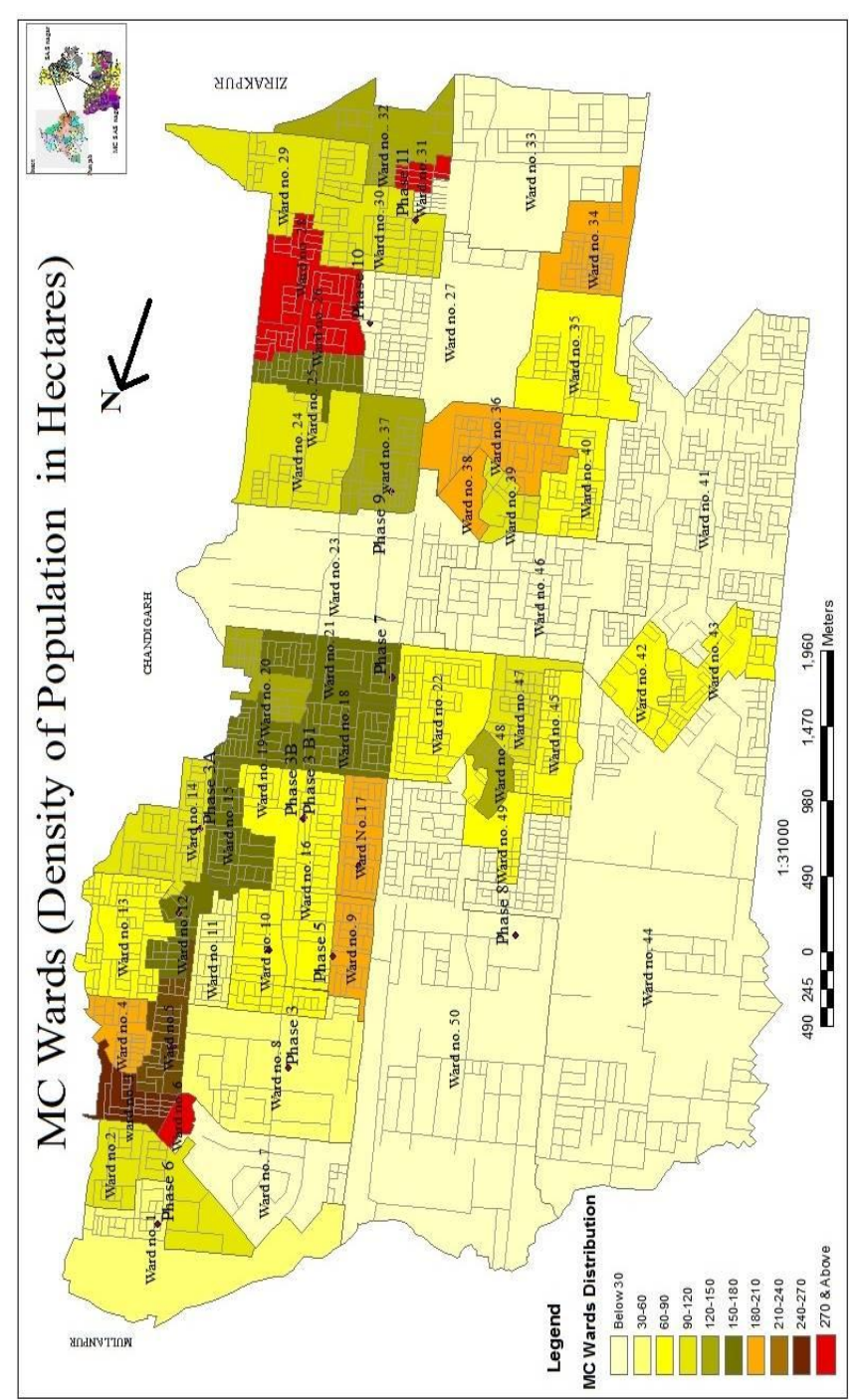

Source: Prepared by Author by using Google Earth \& QGIS and MC SAS Nagar (Mohali) (2016)

Fig. 10 Population Density in MC Wards of Mohali. 


\section{BASIC INFORMATION OF SAS \\ NAGAR (MOHALI) AND MC MOHALI (CENSUS OF INDIA, 2011)}

Population of MC wards: - 146213,

Total area of MC: - 3258 hectares,

Total Population of SAS Town:- 166864 (2011),

Total area of the SAS town $=16767.4$ hectares,

Total Population of SAS District:-994628(2011) $\{$ males $=$ 529,253, Female $=465375\}$, Population Density: -7243 per sq.km.

\section{ANALYSIS OF HEALTH CENTERS FACILITIES}

SAS Nagar has advanced medical facilities which cater to the needs of the residents of the city as well as the surrounding regions. The main hospitals are the IVY hospital (sector 71), silver oak (sector $63 \&$ phase 9), Civil hospital (phase 6), Fortis hospital (sector 62) and Indus super specialty hospital (near Franco hotel). In addition, the city has also Prime heart hospital (sector 69) and Shri Guru Harkrishan eye hospital (village Sohana).

\section{A. Nursing Homes}

Under the Administration's policy for Conversion of Residential Area into Nursing Homes, a number of nursing homes are running in residential areas. Nursing home sites have also been planned in many Sectors (like as Chawla nursing home) which are providing basic/specialized facilities to the city residents.

\section{Dispensaries and Polyclinics}

The city has a large number of Civil Dispensaries, Ayurvedic and Homeopathic dispensaries spread all over the city along with Poly Clinics (Community Health Centers) which cater to Primary and Secondary Health needs of the citizens like as Noor dental clinic, oral healthcare center \& clinic and Aman scanners and clinics.

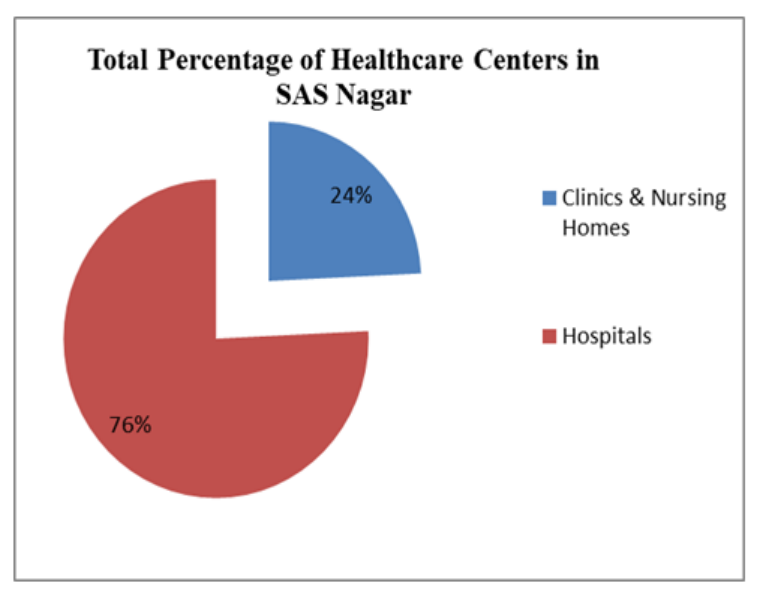

Source: Primary Calculated Value in QGIS

Fig. 11 Percentage of total Hospitals and Health care in SAS Nagar, Mohali

\section{Location Based Analysis}

There are various health care centers in the SAS Nagar (Mohali) including multispeciality hospitals, Clinics and nursing homes etc. The hospitals are situated in the MC area of the SAS Nagar (Mohali), mainly on the minor arterial roads like Silver oak hospital \& Fortis hospital and collector roads in the MC area like as ESI hospital,Sohana hospital \& Chandan hospital etc. Mainly the service areas of these hospital do not covers the whole SAS Nagar (Mohali) area because these hospitals are mainly in the north-eastern part of the SAS Nagar (Mohali) (in MC). There are also various clinics and nursing homes, which covers small part of north eastern part of the SAS Nagar (Mohali) only. It mainly located in close vicinity of the residential areas, industrial areas and commercial areas.

\section{Area Based Analysis}

There are various health care centers in the SAS Nagar (Mohali) inlcluding multispeciality hospitals, Clinics and nursing homes etc.

\section{a. Hospitals}

In case of hospitals, the area under the buffer area of 500 meters \& 1000 meters comes under the good service area for medical facilities. The area under the buffer area of 1500 meters \& 2000 meters is said to be the moderate service area for medical facilities and the area comes the buffer area of $2500 \& 3000$ meters area is to be the poor service area for medical facilities but some areas which are much away from the buffer area of 3000 meters are said to be very poor service areas for medical facilities. So the new proposals of hospitals are made for the poor service area and very poor areas of medical facility like as Village Shanpur, Daun in 122 sector and the residential areas like as Jujhar nagar, sunny enclave 124 sector, Model town in 126 sector,Sante majra in 127 sector, other villages like as Chilla, Nanu Majra, Manak majra and other sectors like as $81,82,83,84,85,86$ and $92,93.94,97,98$ and $122,123,124$, 125126 and 127 sector are all comes under poor or very poor service areas under medical facilities by hospitals as shown in fig. 12.

\section{b. Polyclinics and Nursing homes}

In the case of nursing homes and polyclinics the areas under 500 meters of buffer area are good service area for medical facilities, the areas under 1000 meters of buffer area are moderate services area for medical facilities and the area under 1500 meters of buffer area are poor services for medical facilities and areas farther away from 1500 meters of buffer area comes under very poor services areas for polyclinics and nursing homes type small medical facilities like as the area comes ouside from the MC area of the SAS Nagar (Mohali)because outside the MC area the polyclinics only serve sector 122 and 123 . 
The rest of the sectors outside the MC area need the new proposals for the small medical facility centers like as polyclinics and nursing homes for immidate medical services in any critical situations. In the MC area boundary the area or sectors like as $56,57,72,73,75,76$ upto 80 and 64 , 65,67 and half 68 sector is also unserved or poorly served sectors in case of polyclinics as shown in fig. 13 .

\section{Population Based Analysis}

In the healthcare centers analysis, in maximum no. of cases, the areas which are at the outgrowth or outside the MC or city area are poorly served by the health care centers like as other components of social infrastructure.

\section{a. Hospitals}

In the case of hospitals, mainly the population outside the $\mathrm{MC}$ area or present at the outgrowth areas are moderately, poorly or very poorly served by the hospital services in the coverage area of up-to $3000 \mathrm{~m}$.sq buffer.

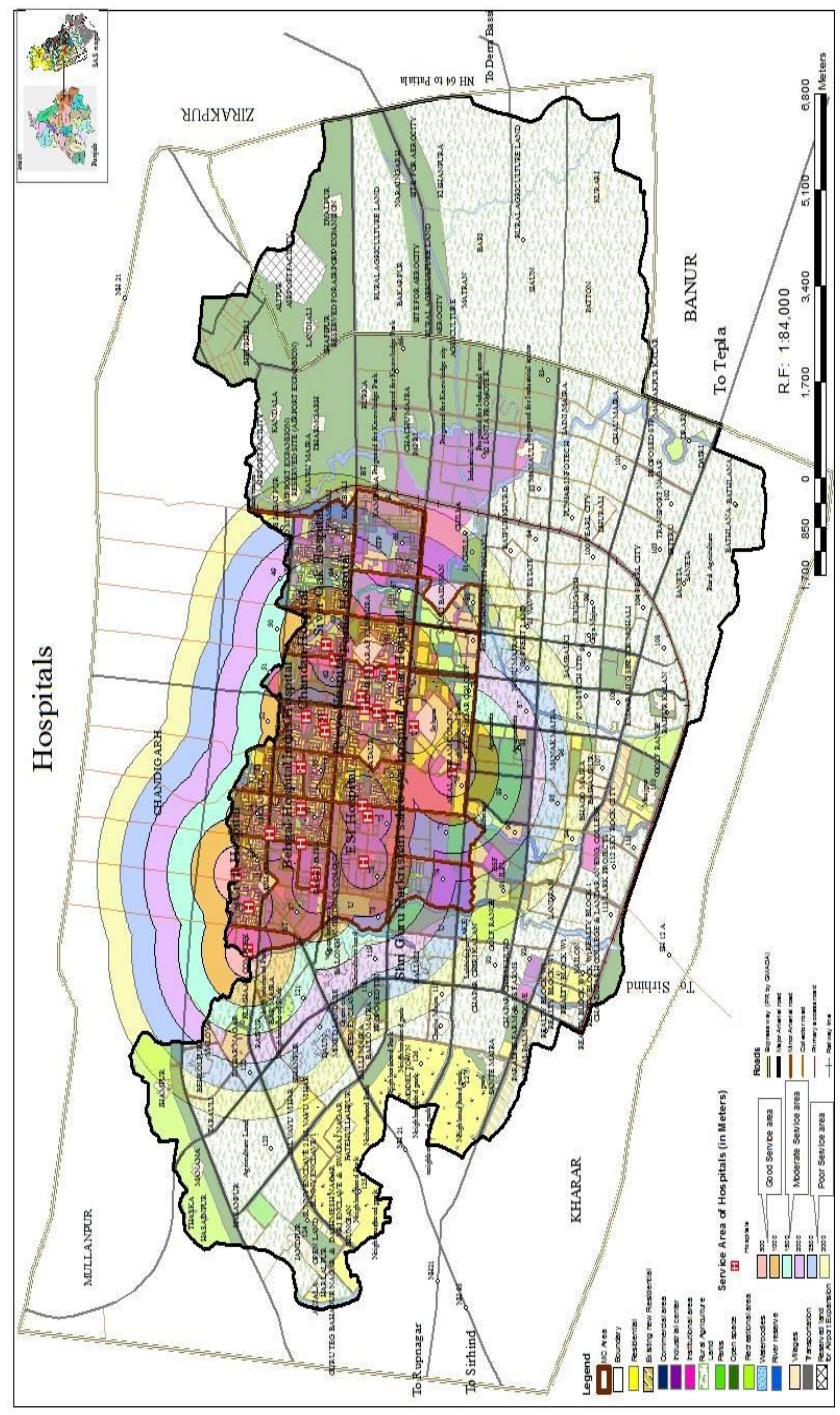

Source: Prepared by Author by using Google Earth \& QGIS (2016) Fig.12 Analysis of Service area by Hospitals at different neighborhood levels in SAS Nagar, Mohali
The polpulation of the areas like as $92,93,109,110,111,112,113,114, \& 124,125$ sector, 126 sector, 127 sectors and villages like as Rurka, Dyalpur, Baliali village, Kailon village, Sante Majra, Chajju majra village, Dyalpur village, Bari village, Patton village, Kurari village, Dairi village, Bathlana Village, Matran village, Bakarpur village, Naraingarh village, Kishanpura village, Alipur village, Siaun village,Landran and Jheurheri village, Manak majra etc. are very poorly served for the nearest location of hospitals, specially in case of emergency.

\section{b. Polyclinics and Nursing Homes}

In the case of nursing homes, it only serves the Mc area of the SAS Nagar (Mohali)at maximum extent of the distance of 2000 m.sq of buffer area. Even the Some important areas or wards under MC are also poorly served by the polyclinics and the nursing homes. Even the maximum Outgrowth area and outer area \& sectors beyond from the MC limit or city area are very poorly served by the polyclinics \& nursing homes. Only the area of 121 sector \& 122 sector is served by the polycinics outside the City limit or MC limit.

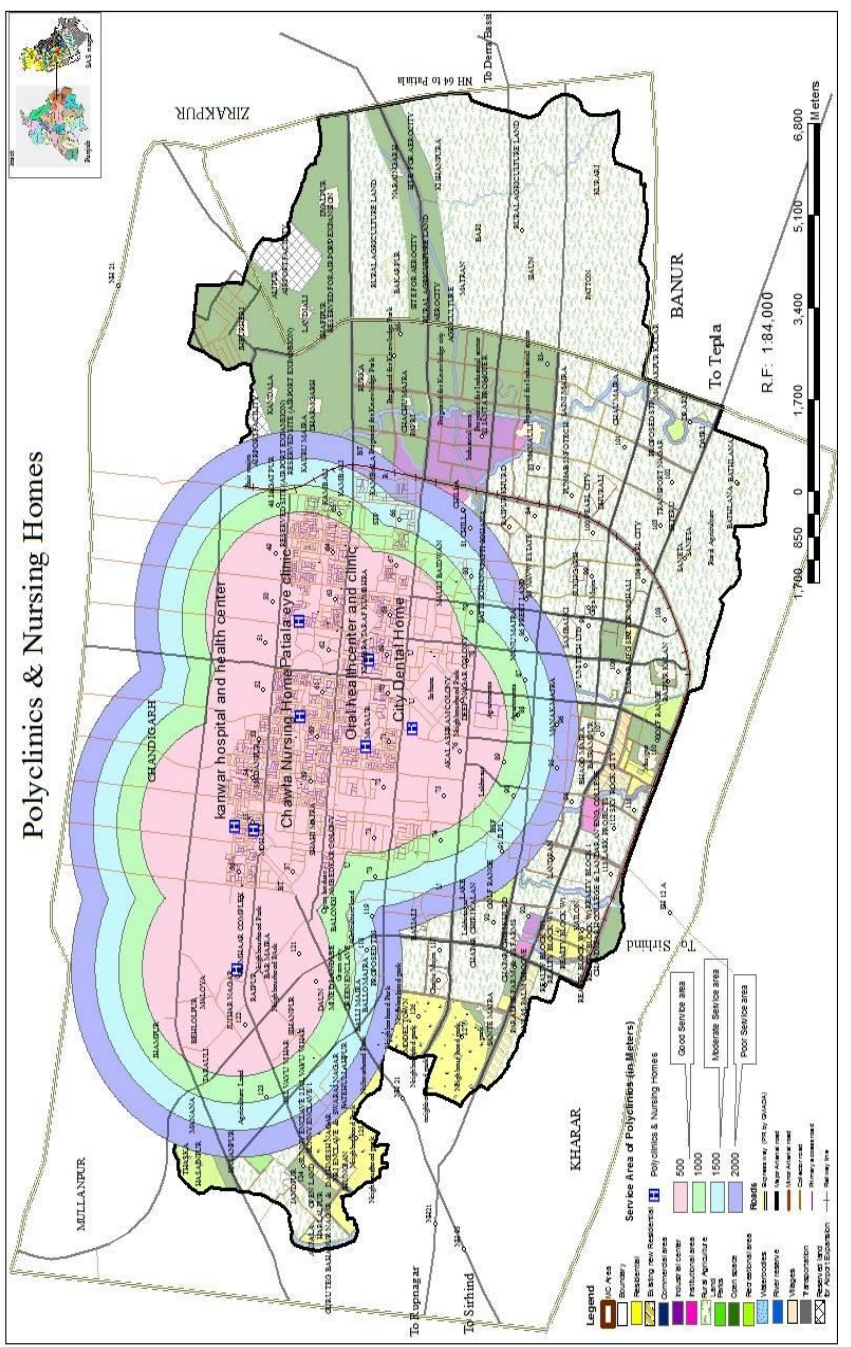

Source: Prepared by Author by using Google Earth \& QGIS (2016) Fig.13 Analysis of Service area by Polyclinics \& Nursing homes at different neighborhood levels in SAS Nagar, Mohali 


\section{ANALYSIS OF HOTELS INFRASTRUCTURE}

SAS Nagar (Mohali) was originally planned for equal distribution of facilities catering to the administrative functions for which the city was envisaged. However, along with the Chandigarh and former part of Chandigarh or counter Magnet part near to Chandigarh, many famous organizations act as the nodal agencies to promote tourism in and all around SAS Nagar (Mohali) like as Chandigarh was the main force behind development of tourist accommodation in terms of hotels and lodges like Hotel Mount view, Shivalik View, Park View and hotel blue Diamond, Hotel Sun View etc. The market force had a large concentration of economical tourist hotels in north eastern side of the SAS Nagar (Mohali)in sector 58, 59, 60, 61 $, 62,63$ and 65 in SAS Nagar (Mohali)and some hotels are on Himalayan marg. The conversion of industrial sites to commercial has resulted in concentration of a new hotel zone in the Industrial Area of the city near Shahi Majra.

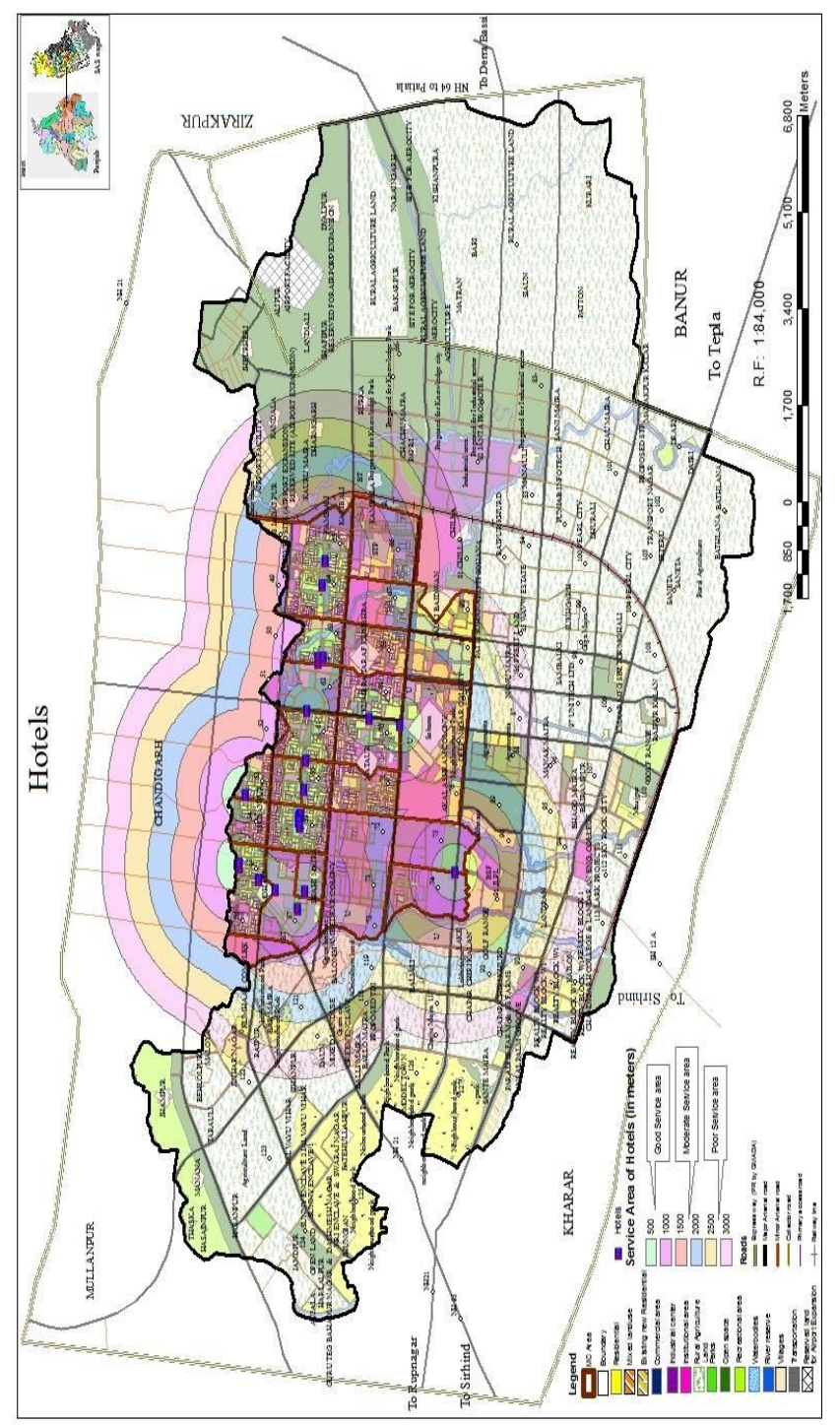

Source: Prepared by Author by using Google Earth \& QGIS (2016) Fig.14 Analysis of Service area by hotels at different neighborhood levels in SAS Nagar, Mohali

\section{A. Location Wise Analysis}

Mainly all the hotels are situated near the Bus stops and terminal. It mainly situated along the major arterial roads like as hotel Swaran, hotel Sunshine \& hotel Ocean and minor arterial roads like as hotel Royal lodge \& hotel Ek noor but some hotels are also present along the collector roads like as hotel Sarab. All the hotels are present in the MC area in north-eastern part of the SAS Nagar (Mohali). So it serve the whole important parts of SAS Nagar (Mohali) like as Bus stops and other terminals.

\section{B. Area Wise Analysis}

Mainly the hotels are served the whole area of SAS Nagar (Mohali) where it is needed for various purposes. So there is no need for new proposals of hotels in MC area. It is only required the new proposals of new hotels outside the MC boundary if needed according to the Master plan or new terminals or tourist spots as shown in fig. 14 .

\section{Population Based Analysis}

In the case of hotels services, the whole MC Population,which $(146,213)$ is good or moderately served by the services of the hotels because all terminals, important educational institutes and recreational areas like as Cricket stadium of Mohali is in the City area or MC area, so the tourist population of the SAS Nagar (Mohali) is easily enjoy the good or moderate type of services of the Hotels. The area and sectors outside the MC area are poorly or very poorly served by the Hotels because in actual the population outside the MC or city area donot need the Hotel services or facilities at much extent.

\section{ANALYSIS OF GREEN SPACES AND PARKS INFRASTRUCTURE}

The green spaces and parks play a vital role in the landscape architect of the town or city. Actually it depicts its effect on the landscape beauty of the city or town and provides proper space for ventilation and free space for greenery in the city. The peoples of the city use these places as recreational purposes, small meetings and for relaxation also like as Rose Garden and other Parks.

\section{A. Location Wise Analysis}

The green spaces (parks only) are mainly present in the residential areas mainly along the minor roads, collector roads and primary access roads. But some of the main neighborhood parks are situated along the major arterial road like as Neighborhood Park of 11 phases.

\section{B. Area Wise Analysis}

Mainly the green areas or Parks serve the whole spaces and areas of SAS Nagar (Mohali), so there is not having any problem of regarding green spaces and parks as shown in fig. 15 . 


\section{Population Based Analysis}

In the case of green spaces and Parks it mainly serves the whole SAS Nagar (Mohali) population $(166,864)$. There is not having any problem of the service or facility of parks \& green spaces to the population of SAS Nagar (Mohali), either in MC or city are or their Out growth and periphery area.

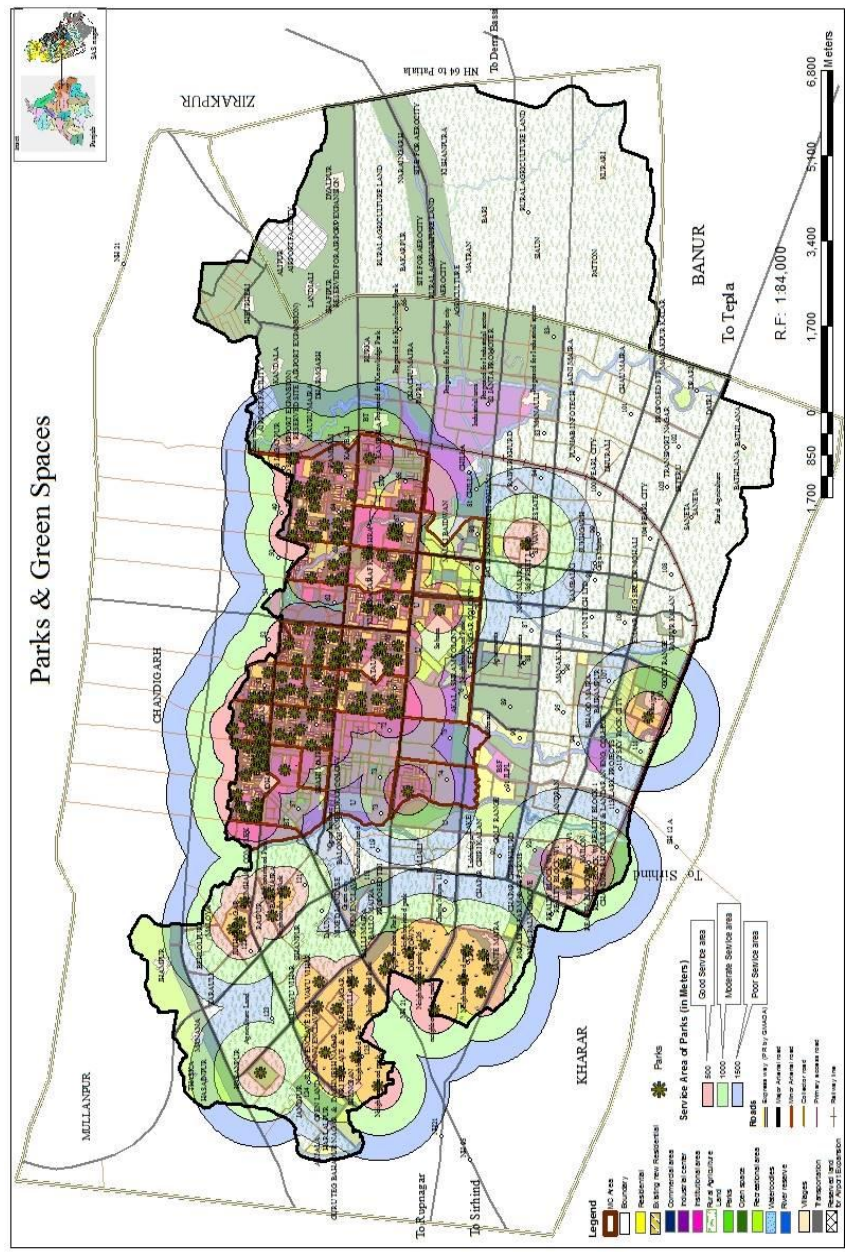

Source: Prepared by Author by using Google Earth \& QGIS (2016). Fig.15 Analysis of Service area by Green Spaces at different neighborhood levels in SAS Nagar, Mohali

\section{ANALYSIS OF BUS STOP \& BUS STAND INFRASTRUCTURE}

This Social infrastructure plays a vital role in the transportation of the city by providing proper spaces for Bus Stands, Taxi stands and Bus stops. It becomes a good facility of the peoples and residents of the town to enjoy the public transportation services from specific place to their destinations during morning, noon and evening timings and also enjoy late night bus services.

\section{A. Location Wise Analysis}

The Bus stops, taxi stands and Bus stands are present in the SAS Nagar (Mohali) mainly in the MC area. The very less bus stops are present outside the MC boundary along the major arterial roads, minor arterial roads and collector roads. Bus stand is present in sector 68 in SAS Nagar (Mohali) near the city park.

\section{B. Area Wise Analysis}

In area wise analysis the Bus stops serve the many areas of SAS Nagar (Mohali) but there services is divided into good, moderate or bad in terms of distance from the bus stops . The area comes under the buffer area of 500 meters \& 1000 meters said to be the good service area for this facilities and the area comes under the buffer area of 1500 meters \& 2000 meters area said to be the moderate service area but some areas which are much far away from the buffer area of 2000 meters are said to be very poor service areas like as sector $72,74,75,82$ and $124,125,126$ and 127 etc. there is very less service of proper bus stops outside the MC area to the village sides and north-western direction as shown in fig. 16.

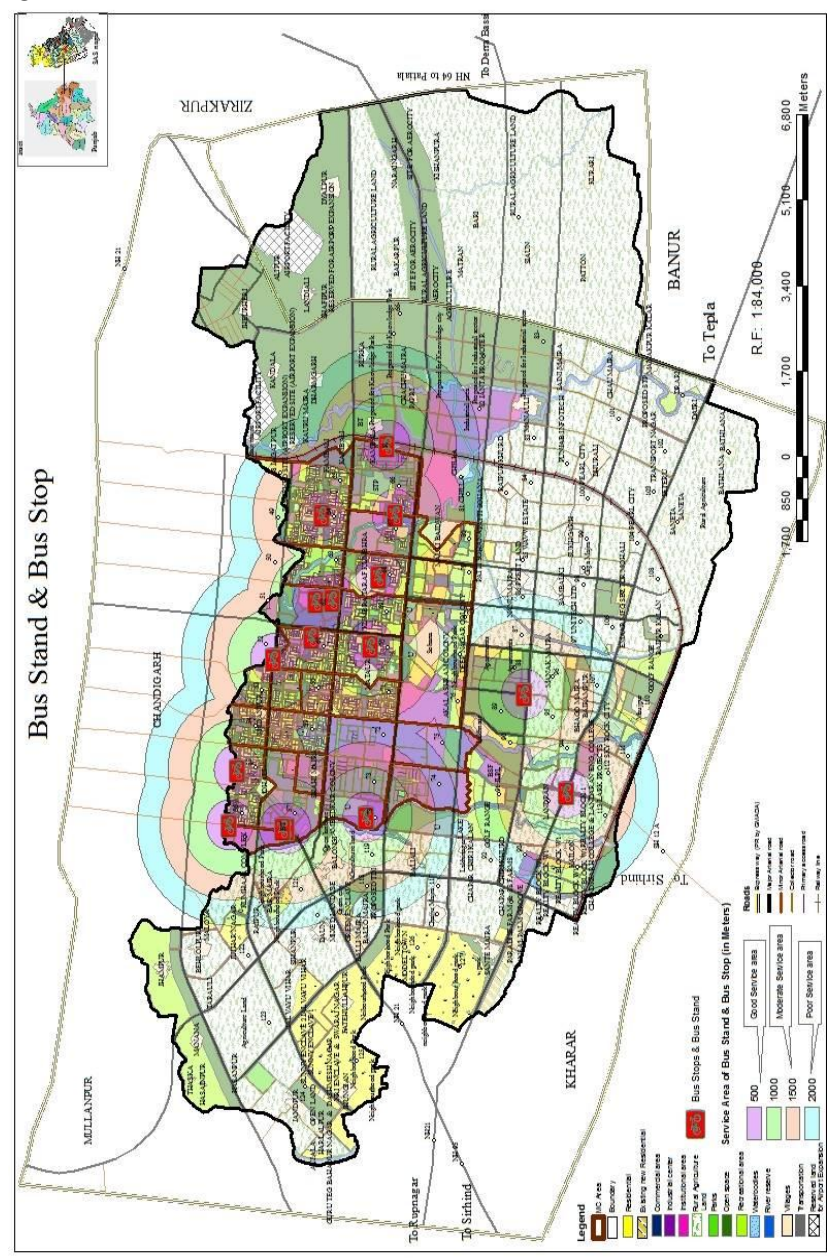

Source: Prepared by Author by using Google Earth \& QGIS (2016) Fig.16 Analysis of Service area by Bus Stops at different neighborhood levels in SAS Nagar, Mohali

\section{Population Based Analysis}

In the case of Bus stands \& Bus stops, It mainly serves the maximum population of MC area or city area but in the outer area of $\mathrm{MC}$ it only serves the population of few sectors in good service or in moderate service like as 87 sector, 88 sector, 89 sector, 91 sector, 92 sector, 94 sector, 
111 sector, 112 sector and 113 sector, 118 sector, 119 sector, 121 sector. Other than these sectors in outside the MC area or City area, the rest of the sectors and villages population are very poorly served by the Bus stops and Bus stand facilities.

\section{ANALYSIS OF BANKS INFRASTRUCTURE}

Banks are also the important component of Social infrastructure of the city or town by providing facilities of economic means and finance related like as provide loans for agricultural works, home loans and personal loans etc. which make the economic status of the existing population and also effect the standard of living of the peoples of the town and play an very significant role in the economy set up of the town or city. SAS Nagar (Mohali) consists of 109 banks of different companies like as ICICI, Yes Bank, HDFC, SBI, SBOP and Axis bank etc. Mainly the maximum banks are found in the middle, northern part and north-eastern part of the town or city. Mainly the sectors of $57,58,59,60,61,65,66,68,67$, and 74 etc.

\section{A. Location Wise Analysis}

There are mainly all banks are situated in the SAS Nagar (Mohali). The most of the banks are situated in the MC area of SAS Nagar (Mohali) along the residential areas , industrial landuse area and institutional landuse area. The MC area have highest density of population areas and wards in which the large part of population is living over there, so that's why maximum number of banks are situated there along with the minor arterial roads and the collector roads. Some few numbers of banks are present in th northern part, north-western part,southern part and 10south western part of the SAS Nagar (Mohali).

\section{B. Area Wise Analysis}

In the case of Banks, according to the norms \& standards, the area comes under the buffer area of 500 meters \& 1000 meters said to be the good service area for bankscfacilities and the area comes under the buffer area of 1500 meters \& 2000 meters area said to be the moderate service area for banks facilities and the area comes under the buffer area of $2500 \& 3000$ meters area and far from this distance is said to be the poor service area for banks facilities. Mainly there are many branches of banks of different companies in the SAS Nagar (Mohali) like as Axis banks, SBOP, SBI and HDFC etc. which covers the whole SAS Nagar (Mohali) as shown in fig. 17.

\section{Population Based Analysis}

In the case of banks, the maximum population of the SAS Nagar (Mohali) is served by good sevice, moderately service and poor service. But the banks in the SAS Nagar (Mohali) serve the whole area of SAS nagar town by their services. Only there are few villages, which are very poorly served by the Banks services like as Dyalpur Village, Kishanpura Village, Landiali village, Jheurheri Village,
Alipur Village, Naraingarh village, Jhampur village and Manana, Thaska village.

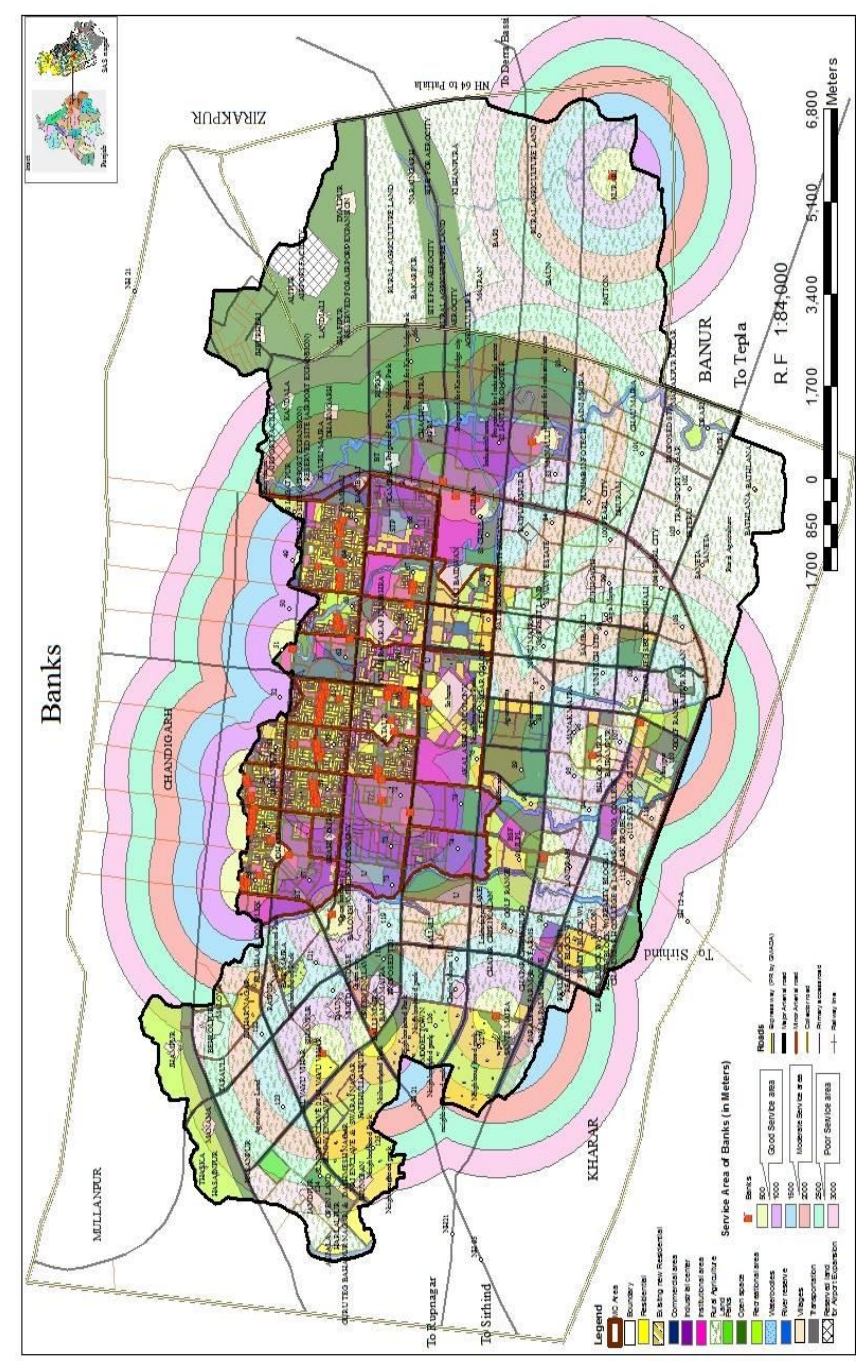

Source: Prepared by Author by using Google Earth \& QGIS (2016). Fig. 17 Analysis of Service area by Banks at different neighborhood levels in SAS Nagar, Mohali

\section{ANALYSIS OF SHOPPING CENTERS INFRASTRUCTURE}

SAS Nagar (Mohali) consists of many shopping malls are the part of commercial sector. Mainly the Northern part and north eastern part of SAS Nagar (Mohali), sectors 58, 59,60, and 61 consist of Shopping Malls around them like as Acer mall, Cell city mall, Connect care mall and The Classic mall in 66 sector. The sector 118 and 74 also consist of malls (North Country \& Mall matrix mall).

\section{A. Location Wise Analysis}

The Shopping centers are mainly situated along the minor arterial \& collector roads and are present in the northeastern part and very few in the south-eastern part of the SAS Nagar (Mohali). These shopping centers are situated near the residential areas and in industrial landuse areas in the commercial sites. 


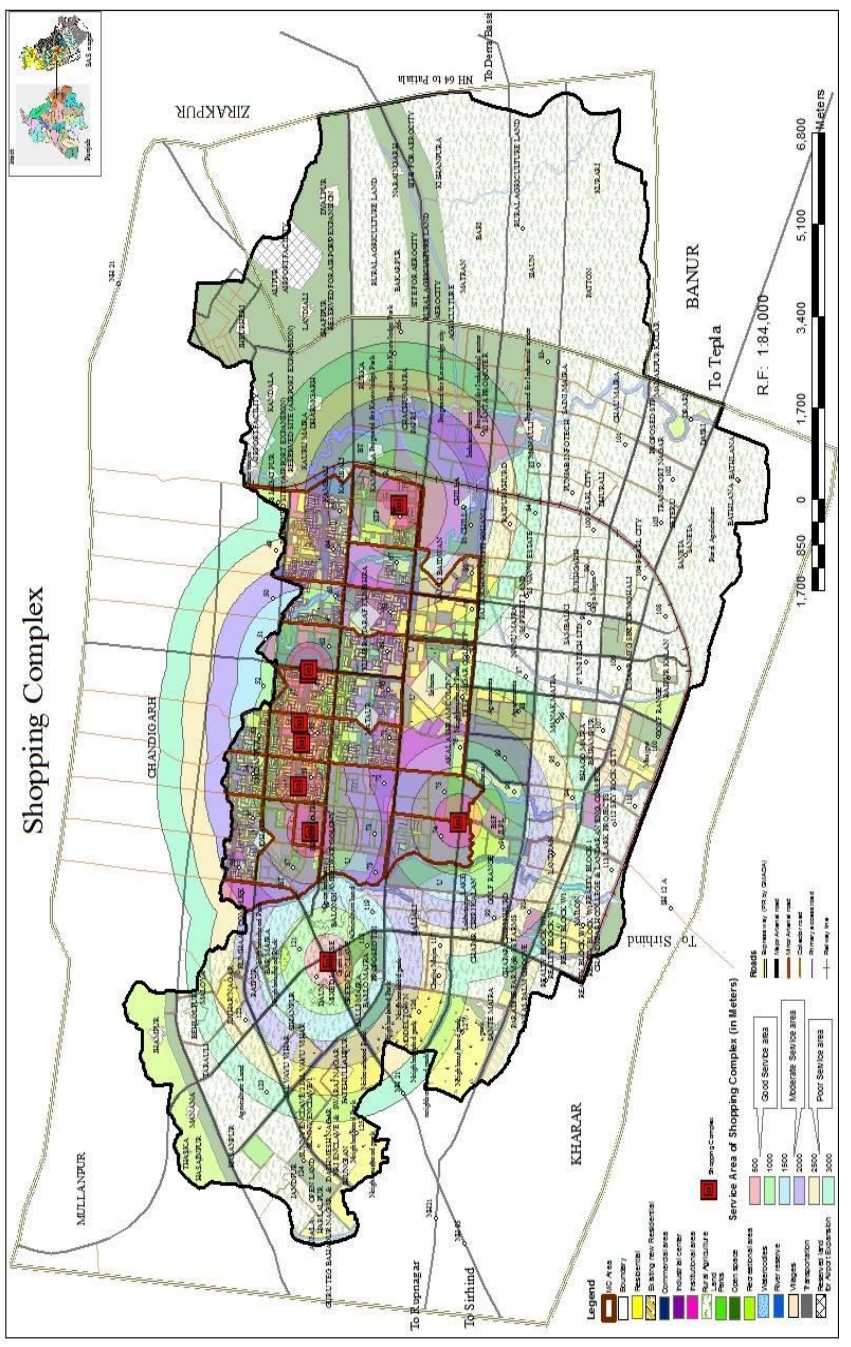

Source: Prepared by Author by using Google Earth \& QGIS (2016). Fig. 18 Analysis of Service area by Shopping Centers $s$ at different neighborhood levels in SAS Nagar, Mohali

\section{B. Area Wise Analysis}

In area wise analysis, the main shopping centers mainly serve the area comes under the buffer area of 500 meters \& 1000 meters said to be the good service area for Shopping centers and the area comes under the buffer area of 1500 meters \& 2000 meters area said to be the moderate service area for shopping centers facilities and the area comes under the buffer area of $2500 \& 3000$ meters area said to be the poor service area for shopping center facilities but some areas which are much far away from the buffer area of 3000 meters are said to be very poor service areas in case of shopping centers like as 121,122,123,124,126,127,125 sectors and the villages like as Landran, landiali, Nanu majra and Raipur khurd etc as shown in fig. 18.

\section{ANALYSIS OF SAFETY AND SECURITY INFRASTRUCTURE}

This component of the social infrastructure provides the facility and service of safety and security the residents and other population of the city or town. It mainly includes the services of police station location with its service area, fire station with its service area and police post with its service area.

The SAS Nagar (Mohali) consist of only single service of Fire station for the whole SAS Nagar (Mohali) and have also many police stations in different locations according to their service boundaries and service areas like as police station of phase 1, phase 8, Mataur police station (7 phase), police station of Sohana sahib near gurudwara sahib and Balongi police station etc.

These police stations also include many police posts under it for providing immediate services to the peoples from near to police post during problems and crime.

\section{A. Location Wise Analysis}

There are total 11 police stations are present in the SAS Nagar (Mohali)city area under which there are many police posts which location is changes according to day and night $\&$ also according to need for police post in the city area and their periphery. Actually the police stations are present in the residential areas, industrial land use area and near to commercial areas. These police stations serve the whole city area and periphery area of the SAS Nagar (Mohali) by their service area up to $5-7 \mathrm{~km}$ buffer around it.

\section{B. Area Wise Analysis}

In the area wise analysis, the police stations buffers cover the area up to $7 \mathrm{~km}$.sq of the area in SAS Nagar (Mohali), which covers the whole SAS Nagar (Mohali). In this coverage area, many police posts are established in different places according to the needs \& situations. These police posts are changed day by day according to the need of an area and place. It's only a one fire station is exist in the SAS Nagar (Mohali), which serve only 73,72,59,60,56,55,54 and a half portion of $71 \& 61$ sector as the time distance of $5-7$ minutes or the area distance of 2-3 Km.sq buffer area.

It's also include the villages like as Shahi majra, Daun and Bar majra which near areas are good served by the fire station but the area beyond this distance is moderately \& poorly served by the Fire station. Even the Periphery area of the MC of SAS Nagar (Mohali)is poorly served by the Fire station which include the the sectors like as $67,66,64,80 \&$ 79 sectors.

But the area beyond this like as from 83 up to 114 sectors and the half parts of $123,125,126$ and 127 are also poorly served by the Fire station. The area towards southern side of the SAS Nagar (Mohali) like as Patton village, Kurari, Bari \& Kishanpura villages etc. are very poorly served by the fire station. The southern - eastern side of SAS Nagar (Mohali) is also poorly served by the fire station as shown in fig. no. 19. 


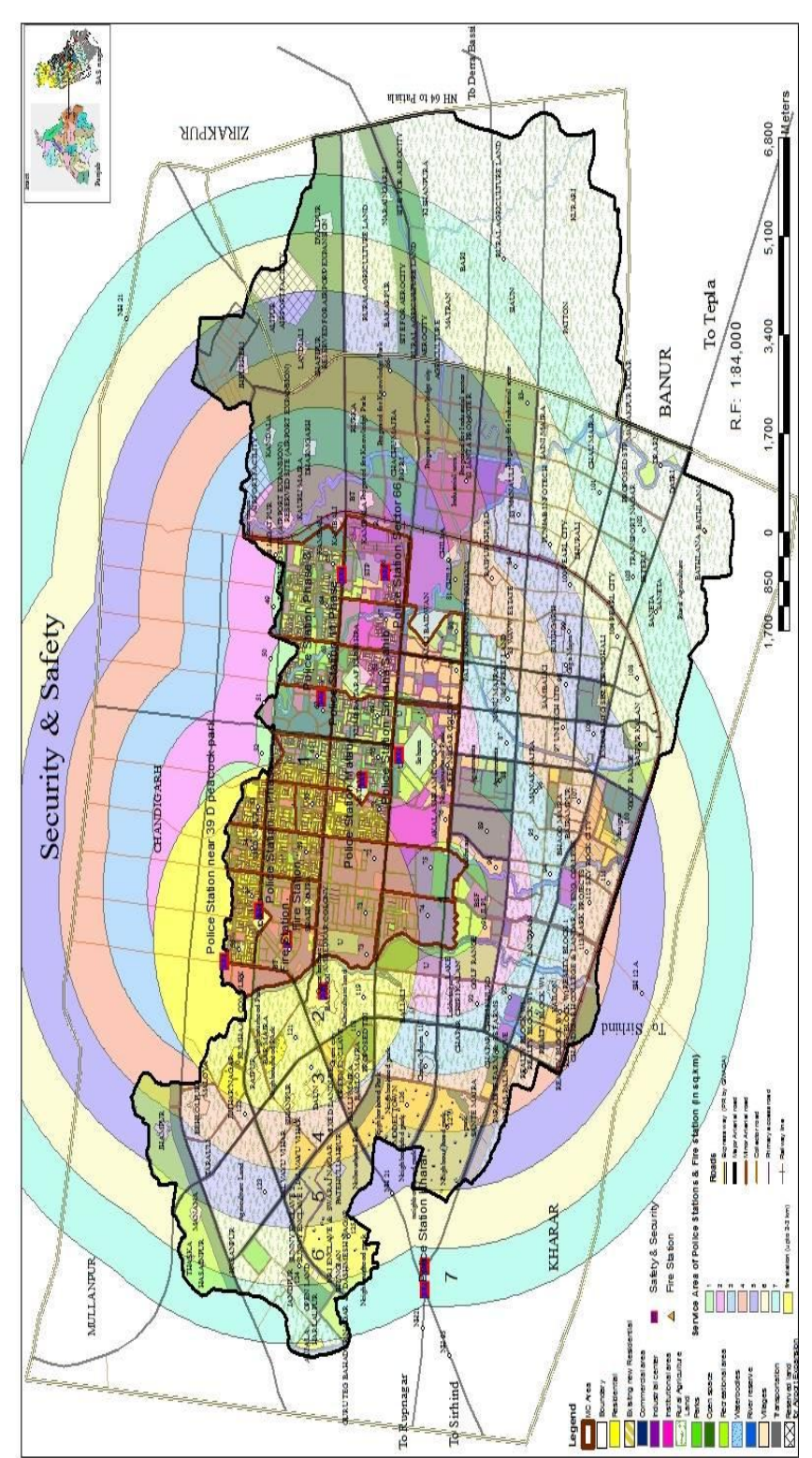

Source: Prepared by Author by using Google Earth \& QGIS (2016). Fig.19 Analysis of Service area by Security \& Safety stations at different neighborhood levels in SAS Nagar, Mohali

\section{CONCLUSION}

From the above done analysis it is concluded that the city is not having proper social infrastructure in some areas as according to the increase in the urbanization and population of the Mohali. The main problem occurring due to this component is of congestion, encroachment in the center of the town and the institution which having less space according to the norms \& standards. Due to lacking of parking spaces because of which there is traffic problem in those areas. These facilities are most present in the northern side of the city hence the southern side of the city is lacking in these facilities. The institutional areas and recreational grounds should be proposed near to the residential areas to avoid the problems like roadside parking, traffic congestion, and nuisance will get avoided or surrounding land use of the institution also check to avoid future problems. The entry or exit gates should not open on the main road. There is an need to increase the commercial land use near to the more density of areas of population and also increases the areas for polyclinics outside the $\mathrm{MC}$ areas, so that it could easily serve the outside area from MC.

\section{ACKNOWLEDGEMENT}

The author thankfully acknowledges the Greater Mohali Development Authority and MC Mohali for providing the MC map of the SAS Nagar (Mohali) for the Purpose. The author also thankful to the Associate Professor (GRD School of Planning, GNDU, Amritsar) Mr. GK Johari for providing the academic and guidance support in this research.

\section{REFERENCES}

[1] Aggarwal, Meena. (1991). Changing structure of a small town: case study Gangaghat (U.P.), Unpublished Thesis, School of Planning and Architecture, New Delhi, India.

[2] Aggarwal, Y. P. (1988). Education and Human Resource Development, Common wealth publisher, New Delhi.

[3] Ganesan, S. (ed) (2001). Infrastructure Development and Financing. Kanishka Publishers \& Distributors, New Delhi.

[4] Heggade, Udeyar, D. (2002). Infrastructure Development Under Economic Reforms. Mohit Publications, New Delhi.

[5] Kareem, A. (1988). Educational and Socio-economic Development, Ashish Publishing House, New Delhi.

[6] Municipal Corporation of Amritsar. (2008, August). City Development Plan 2006 - 2025.

[7] Punjab Urban Planning \& Development Authority (PUDA) Mohali, (2010). Draft Master Plan Amritsar 2010-2031, Punjab.

[8] GMADA, (2011). Master Plan for Greater Mohali region - 2021.

[9] Ministry of Urban Development. (2014, February). URDPFI Volume I First Draft Report.

[10] Local Government Areas. (2015, May). Comparative Study of Social Infrastructure Provision in Ikwerre and Etche of Rivers State Using Geographic Information System, SCIRJ, 3(5).

[11] Ilhamdaniah. (2005). The Planning for Social Infrastructures Provision Case Study: Ahmedabad, India.

[12] Laveesh Bhandari. (2006). Social Infrastructure: Urban Health and Education.

[13] (2009). Social Infrastructure Issues Paper to Inform LDF Development Management DPD.

[14] City of Charles Sturt. (2011). Planning Social Infrastructure and Community Services for Urban Growth Areas, South Australia.

[15] Retrieved from http://www.treasury.govt.nz/abouttreasury/ higherlivingstandards January 2013, Accessed on 15th march, 2016.

[16] Retrieved from http://www.cde.ca.gov/ls/fa/sf/schoolsiteguide.asp Accessed on 15th march, 2016.

[17] Retrieved from http://chandigarhmasterplan.com/zonalplansmpd 2021/ urbanextensionprojects/ ahmedabad/ Accessed on 12th January, 2016.

[18] Retrieved from www.undp.org/poverty/docs/fpage/Synthesisreport. pdf, (2005). Accessed on 23rd January, 2016. 